\title{
Peran Media Pembelajaran Dalam Pembelajaran Bahasa Indonesia
}

\author{
Rahmiyyatul Husna/19016116 \\ rahmirahmihusna@gmail.com
}

Dalam memberikan sebuah pesan atau informasi, khususnya dalam proses kegiatan belajar mengajar, diharapkan adanya media serta alat bantu pembelajaran yang akan dapat membantu tercapainya tujuan pembelajaran yang diharapkan. Pendidikan adalah alat untuk mengembangkan dan meningkatkan kualitas sumber daya manusia. Menurut Jasma (dalam Mahendra et all, 2019) Pendidikan diharapkan bisa menimbulkan perubahan pada diri seseorang seperti aspek kognitif, efektif dan psikomotor. Sejalan dengan program peningkatan mutu pendidikan, penggunaan media pendidikan dalam kegiatan belajar mengajar merupakan suatu alternatif yang harus ditempuh bila menginginkan adanya pemahaman materi pembelajaran yang baik dari siswa. Penerapan teknologi pendidikan, khususnya dalam pemanfaatan media pendidikan dalam kegiatan belajar mengajar oleh guru masih dalam kondisi memprihatinkan. Sehubungan dengan itu, sudah selayaknya jika guru mengerti apa dan bagaimana kegiatan belajar mengajar yang efektif dan efisien, serta peranan dari media pendidikan itu sendiri dalam kegiatan belajar mengajar ( Fitri, Y. et all, 2016).

Pada umumnya guru Pendidikan bahasa Indonesia memakai metode mengajar secara kovensional, yaitu guru banyak mengajarkan teori-teori, fakta- fakta, dan masalah-masalah menggunakan metode ceramah saja, sedangkan peserta didik hanya mendengarkan, mencatat dan menghafalkannya saja. Metode yang dapat merangsang minat dan kreativitas siswa terhadap materi pelajaran, yaitu dengan menggunakan media pendidikan sebagai alat bantu mengajar sehingga perubahan yang diinginkan pada diri peserta didik bisa tercapai.

Salah satu kemampuan dasar yang harus dimiliki oleh guru adalah kemampuan menggunakan media pendidikan maupun sumber belajar. Pendayagunaan media pendidikan dan sumber belajar dapat berupa penggunaan alat peraga buatan guru, pemanfaatan alam sekitar untuk belajar, pemanfaatan perpustakaan dan pemanfaatan fasilitas teknologi pendidikan yang lain. Contohnya menulis teks berita siswa menggunakan teknik mind mapping dapat dilakukan dengan analisis per indikator (Mardiah, et al., (2018). Menggunakan media online dalam menganalisis berita di Vivanew.com, Detiknews.com, Kompas.com, Metrotvnes.com dan Sindonews.com dapat digunakan strategi wacana eksklusi dan inklusi (Rilma, A. F. et al., (2019). Dini dan Syahrul (2017:6) mengemukakan bahwa keterampilan 
menulis diterapkan untuk meningkatkan kreativitas siswa sehingga melalui kegiatan menulis siswa dapat menyampaikan ilmu pengetahuan dan informasi yang siswa ketahui kepada khalayak ramai. Adanya media pembelajaran dapat membantu siswa dalam menuangkan gagasan atau ide berdasarkan materi yang diberikan oleh guru karena pada umumnya siswa merasa kesulitan dalam menuangkan gagasan atau ide dalam menulis serta pemilihan diksi yang kurang tepat dalam menulis teks (Syahrul, R. et all., (2019). Menurut Dinarti (dalam Syahrul, R. et al, 2019) penguasaan kosakata siswa sangat kurang sehingga siswa mengalami kesulitan dalam mengembangkan idenya terlihat pada hasil karangan yang dibuat oleh siswa yang sangat pendek.

Peranan media pembelajaran dapat digunakan untuk menyalurkan pesan pengirim kepada penerima dan melalui media pembelajaran juga dapat membantu peserta didik untuk menjelaskan sesuatu yang disampaikan oleh pendidik. Oleh karena itu, guru dituntut untuk menggunakan media di dalam proses pembelajaran. Dengan demikian, melalui media pembelajaran dapat membuat proses belajar mengajar lebih efektif dan efesien serta terjalin hubungan baik antara guru dengan peserta didik. Salah satu media yang dapat digunakan dalam pembelajaran bahasa Indonesia adalah media audiovisual, Hartidini et al (2018) mengatakan bahwa media audiovisual dalam pembelajaran keterampilan menulis karangan argumentasi, dapat membantu pemahaman siswa lebih baik sehingga guru bisa menyesuaikan materi pembelajaran dengan waktu yang tersedia dan tujuan pembelajaran pun tercapai dengan maksimal. Selain menggunakan media audiovisual guru juga dapat menggunakan video, dalam proses pembelajaran melalui penerapan media video yang diharapkan dengan meningkatnya motivasi belajar siswa dan dapat pula meningkatkan hasil belajar siswa.(Isral, I. et all, 2019).

Berdasarkan angket yang penulis sebarkan mengenai "Penggunaan Media Pembelajaran Dalam Pembelajaran Bahasa Indonesia" kepada siswa dan siswi kelas XI IPS 1 Man 2 Kota Padang Panjang. Dari jumlah keseluruhan 30 responden yang ikut serta mengisi angket tersebut lebih dominan perempuan dengan 16 responden dan laki-laki dengan 14 responden dengan persentase $63,3 \%$ perempuan, 36,7\% laki-laki. Hasil data dari persentase angket yang telah dilakukan melalui google form tersebut dapat dilihat sebagai berikut.

Pernyataan pertama, "Pembelajaran dengan menggunakan media lebih menyenangkan dibanding hanya dengan metode ceramah saja" 33,3\% menyatakan sangat setuju, 60\% menyatakan setuju, $10 \%$ menyatakan tidak setuju, dan $0 \%$ menyatakan sangat tidak setuju. Pernyataan kedua, "Saya lebih bisa mengikuti pembelajaran dengan baik tentang apa yang dijelaskan guru bila menggunakan media dibanding dengan ceramah saja" 26,7\% menyatakan 
sangat setuju, 53,3\% menyatakan setuju, 13,3\% menyatakan tidak setuju, dan 6,7\% menyatakan sangat tidak setuju. Pernyataan ketiga, "Saya lebih menyukai proses belajar mengajar yang interaktif (diskusi, penggunaan media-media, dll) karena lebih cepatmemahami materi pelajaran" 26,7\% menyatakan sangat setuju, 66,7\% menyatakan setuju, 6,7\% menyatakan tidak setuju, dan 0\% menyatakan sangat tidak setuju. Pernyataan keempat, "Dalam mengajar guru menggunakan media pembelajaran yang bervariasi" 26,7\% menyatakan sangat setuju, 73,3\% menyatakan setuju, $0 \%$ menyatakan tidak setuju, dan $0 \%$ menyatakan sangat tidak setuju. Pernyataan kelima, "Guru menggunakan media pembelajaran dalam mengajar" $20 \%$ menyatakan setuju, 76,7\% menyatakan sangat setuju, 3,3\% menyatakan tidak setuju, dan 0\% menyatakan sangat tidak setuju. Pernyataan keenam, "Guru menggunakan media pembelajaran yang bervarias" $70 \%$ menyatakan setuju, 26,7\% menyatakan sangat setuju, 3,3\% menyatakan tidak setuju, dan $0 \%$ menyatakan sangat tidak setuju. Pernyataan ketujuh, "Penggunaan media pembelajaran memberi pengaruh yang sangat besar dalam menerima pelajaran bahasa Indonesia" 46,7\% menyatakan sangat setuju, 50\% menyatakan setuju, 3,3\% menyatakan tidak setuju, dan $0 \%$ menyatakan sangat tidak setuju. Pernyataan kedelapan, "Saya lebih bersemangat mengikuti pelajaran bahasa Indonesia yang menggunakan media pelajaran" $30 \%$ menyatakan sangat setuju, 53,3\% menyatakan setuju, 16,7\% menyatakan tidak setuju, dan 0\% menyatakan sangat tidak setuju. Pernyataan kesembilan, "Saya merasa lebih terbantu memahami materi Bahasa Indonesia setelah guru menggunakan media pelajaran" 20\% menyatakan sangat setuju, 73,3\% menyatakan setuju, 6,7\% menyatakan tidak setuju, dan $0 \%$ menyatakan sangat tidak setuju. Pernyataan kesepuluh, "Saya lebih rajin belajar karena media pembelajaran membuat saya menyukai pelajaran bahasa Indonesia" 50\% menyatakan setuju, $33,3 \%$ menyatakan sangat setuju, 16,7\% menyatakan tidak setuju, dan $0 \%$ menyatakan kurang setuju.

Dari hasil penyebaran angket yang telah dilakukan, dapat penulis simpulkan bahwa penggunaan media pembelajaran oleh guru dapat membantu siswa dalam memahami materi pembelajaran dengan lebih baik, dari pada hanya menggunakan metode ceramah dalam menjelaskan materi pembelajaran, dengan adanya media pembelajaran yang berfariasi hal ini dapat meningkatkan daya tarik siswa dalam memperhatikan pembelajaran. Peran media pembelajaran sangat membantu berjalanya proses pembelajaran baik di sekolah maupun di luar sekolah, media pembelajaran juga dapat membantu guru dalam mempermudah guru dalam proses pembelajaran. 


\section{DAFTAR PUSTAKA}

Dini, R Syahrul, dan Tressyalina. (2017). Hubungan Penguasaan Kosakata Bidang Jurnalistik dengan Keterampilan Menulis Teks Berita Siswa Kelas XII SMK Negeri 2 Bukittinggi. Jurnal Pendidikan Bahasa dan Sastra Indonesia. 6(2). Pp. 257-263.

Fitri, Y., Syahrul, R., \& Tamsin, A. C. (2016). Pengaruh model pembelajaran kooperatif tipe think talk write berbantuan media gambar terhadap keterampilan menulis karangan argumentasi siswa kelas X SMA Negeri 5 Padang. Jurnal Pendidikan Bahasa dan Sastra Indonesia, 5(2), 548-554.

Halawa, N., Gani, E., \& Syahrul, R. (2019). KESANTUNAN BERBAHASA INDONESIA DALAM TINDAK TUTUR MELARANG DAN MENGKRITIK PADA TUJUH ETNI. Lingua, 15(2), 195-205.

Hartidini, S., Syahrul, R., \& Ratna, E. (2018). Pengaruh strategi pembelajaran inkuiri berbantuan media audiovisual terhadap keterampilan menulis karangan argumentasi siswa kelas X SMA Negeri 2 Lengayang kabupaten pesisir selatan. Jurnal Pendidikan Bahasa dan Sastra Indonesia, 7(1), 63-69.

Isral, I., Syahrul, S., \& Syahri, B. (2019). PENERAPAN MEDIA VIDEO UNTUK MENINGKATKAN MOTIVASI DAN HASIL BELAJAR SISWA PADA MATA DIKLAT TEKNIK BUBUT KELAS XII JURUSAN TEKNIK PEMESINAN SMK N 1 PADANG. Jurnal Vokasi Mekanika (VoMek), 1(1), 1-7.

Mahendra, H., Syahrul, S., \& Syahri, B. (2019). HUBUNGAN PERSEPSI SISWA TERHADAP SARANA BELAJAR GAMBAR DENGAN HASIL BELAJAR MATA DIKLAT GAMBAR TEKNIK PADAKELAS X TEKNIK PERMESINAN DI SMK NEGERI 1 LINTAU BUO KABUPATEN TANAH DATAR. Jurnal Vokasi Mekanika (VoMek), 1(2), 12-22.

Mardiah, M., Syahrul, R., \& Zulfikarni, Z. (2018). PENGARUH PENGGUNAAN TEKNIK MIND MAPPING TERHADAP KETERAMPILAN MENULIS TEKS BERITA SISWA KELAS VIII SMP NEGERI 25 PADANG. Jurnal Pendidikan Bahasa dan Sastra Indonesia, 7(4), 52-57.

Putri, D., \& Syahrul, R. (2019). Korelasi Keterampilan Membaca Pemahaman dan Keterampilan Menulis Teks Laporan Hasil Observasi Siswa Kelas Vii Smp Negeri 4 Pariaman. Jurnal Pendidikan Bahasa dan Sastra Indonesia, 8(2), 62-69. 
Rilma, A. F., Syahrul, R., \& Gani, E. (2019). Strategi Pemberitaan di Media Online Nasional tentang Kasus Tercecernya KTP Elektronik (Analisis Teori Van Leeuwen). Lingua, 15(1), 85-93.

Syahrul, R., Arief, D., \& Maryani, M. (2019). The Effect of Media Use of Comics Without Text and Direct Learning on Narrative Writing Skills for Grade IV Elementary School Student. International Journal of Educational Dynamics, 1(2), 93-98.

Tatalia, R. G., \& Syahrul, R. (2015). Pengaruh Model Pembelajaran Kooperatif Tipe STAD Berbantuan Pemetaan Pikiran (MIND MAPPING) Dengan Mempertimbangkan Motivasi Belajar Terhadap Kemampuan Menulis Teks Berita Siswa Kelas VIII SMP Negeri 1 Panti. Bahasa, Sastra, dan Pembelajaran, 3(1). 